\title{
An application of the extended Technology Acceptance Model in understanding technology-enabled financial service adoption in South Africa
}

\author{
John P Wentzel ${ }^{1}$, Krishna Sundar Diatha ${ }^{2}$ \& \\ VSS Yadavalli ${ }^{3}$
}

The last 10 years have seen a significant increase in the provision of consumer services through technology. Computers, mobile phones, the Internet and self-service kiosks are examples of technology platforms that have enabled services to be offered to consumers in new ways. In South Africa, technology-enabled financial services have the potential to expand financial inclusion, especially at the bottom of the pyramid. There is a need to understand how consumers adopt technology-enabled services. Using grounded theory, an enhancement to the Technology Acceptance Model is proposed and developed to explain adoption of technologyenabled financial services. Confirmatory factor analysis is used to validate the model against data obtained from a survey. The proposed model fits the data well. Implications of the model are discussed.

Keywords: Technology Acceptance Model; technology-enabled service adoption; grounded theory

\section{Introduction}

One of the most significant developments in society over the past 10 years has been the expansion of the delivery of products and services to consumers through the use of technology. Computers, mobile telephones, the Internet and self-service devices are examples of technology platforms that have enabled services to be offered in new and innovative ways. A distinction needs to be drawn between a technology, for example a mobile phone, and a technology-enabled service such as mobile banking. The focus of this paper is investigation of the adoption of technology-enabled financial services by consumers. Financial services are associated with the saving, transfer, payment and movement of money. Technology-enabled financial services have the potential to bring services to customers who are unable to access them using traditional channels.

Despite the considerable political and social changes over the past few years, poverty remains a significant challenge for South Africa (Ngwane et al., 2001a, 2001b). The gap between rich and poor remains high and the country has a Gini coefficient of 63.1, which is the second highest in the world (World Bank, 2009). The role of improved access to financial services in reducing poverty has been recognised

\footnotetext{
${ }^{1}$ Department of Industrial \& Systems Engineering, University of Pretoria, 0002 Pretoria, South Africa.

${ }^{2}$ Professor, Production \& Operationa Management Area, Indian Institute of Management, Bangalore 560076, India.

${ }^{3}$ Professor, Department of Industrial \& Systems Engineering. University of Pretoria, 0002 Pretoria, South Africa. Corresponding author: sarma.yadavalli@up.ac.za
} 
(Tejerina et al., 2006). The South African government has also recognised the role that access to financial services can play in alleviating poverty and has made expanding financial inclusion a cornerstone of policy efforts. The use of technology to deliver financial services has the potential to reduce costs, expand reach and increase availability. The approach has the potential to enable poor people to access services that would otherwise not be economically viable for suppliers to deliver. Understanding how people at the bottom of the economic pyramid adopt financial services is important.

The term 'bottom of the pyramid' was first proposed in an article published in 2002 (Prahalad \& Hart, 2002). The authors divided the global population into four tiers comprising a pyramid. At the bottom of the pyramid were four billion people whose per-capita income based on purchasing power parity was less than $\$ 1500$ per annum, the minimum considered necessary to sustain a decent life. Whilst this presented an untapped market for multi-national corporations, investing in the bottom of the pyramid would mean lifting billions of people out of poverty and desperation. Lifting people out of dire economic conditions would avoid social decay, political chaos, terrorism and environmental meltdown that could arise if the gap between the rich and poor continued to widen (Prahalad \& Hart, 2002). The per-capita income translated into surviving on less than $\$ 4.11$ per day. In a subsequent paper on the same topic, Prahalad \& Hammond (2002) argued that people at the bottom of the pyramid pay higher prices for goods and services compared with middle-class consumers. Thus there was an opportunity for companies with economies of scale and efficient supply chains to capture a market share and enter new markets. A book was subsequently published (Prahalad, 2006) in which the author argued that serving bottom-of-thepyramid customers was not only a profitable opportunity for corporations, but also a social imperative. By addressing the bottom of the pyramid, corporations could curtail poverty and improve the living conditions of the world's poorest (Prahalad, 2006).

\subsection{Technology adoption theory}

A number of theories have been introduced to explain user adoption of technology. The first theory that attempted to explain this process was the Theory of Reasoned Action (TRA) (Fishbein \& Ajzen, 1975; Comrey \& Lee, 1992). The TRA describes user behaviour from a social psychology point. The TRA seeks to identify the causes of consciously intended behaviours, and holds that they are a function of attitude towards the intended behaviour and a person's awareness of the associated social pressures. The Theory of Planned Behaviour (Ajzen, 1991) was an extension of the TRA that attempted to deal with the original model's limitations in resolving behaviour over which people have incomplete control. The Theory of Planned Behaviour suggests that in addition to attitude and social pressures, a third element, perceived behavioural control, also influences intentions and consequently the actual behaviour. The Theory of Planned Behaviour extended the TRA to account for conditions in which individuals do not have full control over the situation.

The first theory to specifically predict the adoption of information technology was introduced by Davis (1986, 1989; Davis et al., 1989). The Technology Acceptance Model (TAM) explained and predicted the behavioural intention and the use of information technology by users in a workplace environment. The TAM introduced two factors that determine user's acceptance or rejection of information technology, 
namely perceived usefulness (PU) and perceived ease of use (PEOU). PU was defined as the degree to which a person perceives that adopting the system will boost his/her job performance, while PEOU was defined as the degree to which a person believes that adopting the system would be free of effort. The TAM is shown in Figure 1.

Many studies have used the TAM to successfully explain and predict the adoption of information technology in a workplace environment (Taylor \& Todd, 1995; Igbaria et al., 1997; Venkatesh \& Morris, 2000; Moon \& Kim, 2001; van der Heijden, 2003; Bruner II \& Kumar, 2005; Luarn \& Lin, 2005; Wu \& Wang, 2005). The success of the TAM resulted in its application extending beyond the workplace environment and into a range of environments including consumer services such as mobile commerce. This resulted in extensions to the original TAM model. The first significant extension was TAM2 (Venkatesh \& Davis, 2000), which extended the original model through the inclusion of social and organisational variables. In TAM2 these factors were shown to have a direct impact on PU.

The second significant extension to the TAM was the User Acceptance of Information Technology. This extension was a consolidation of eight different TAM models into a single theory (Venkatesh et al., 2003). Four additional constructs - namely, performance expectancy, effort expectancy, social influence, and facilitating conditions - were proposed as direct determinants of usage intention and behaviour. The User Acceptance of Information Technology further introduced moderating constructs (gender, age, experience, and voluntariness of use) that were posited to moderate the impact of the four key constructs on usage intention and behaviour.

Despite alternatives, the TAM and its extensions have proven over time to be the most influential technology adoption model (Adams et al., 1992; Venkatesh \& Morris, 2000; Venkatesh et al., 2003; Chuttur, 2009). The application of the TAM beyond the workplace raises problems, since its core constructs do not fully reflect the variety of task environments and how well the technology meets the requirements of that task (Venkatesh, 2000). It has been argued that the TAM has neglected group, social and cultural aspects of technology adoption (Bagozzi, 2007). In addition to personal characteristics, context characteristics play an important role in technology adoption (van de Wijngaert \& Bouman, 2009a, 2009b). It has been proposed that additional factors need to be taken into account when considering the TAM (Chuttur, 2009).

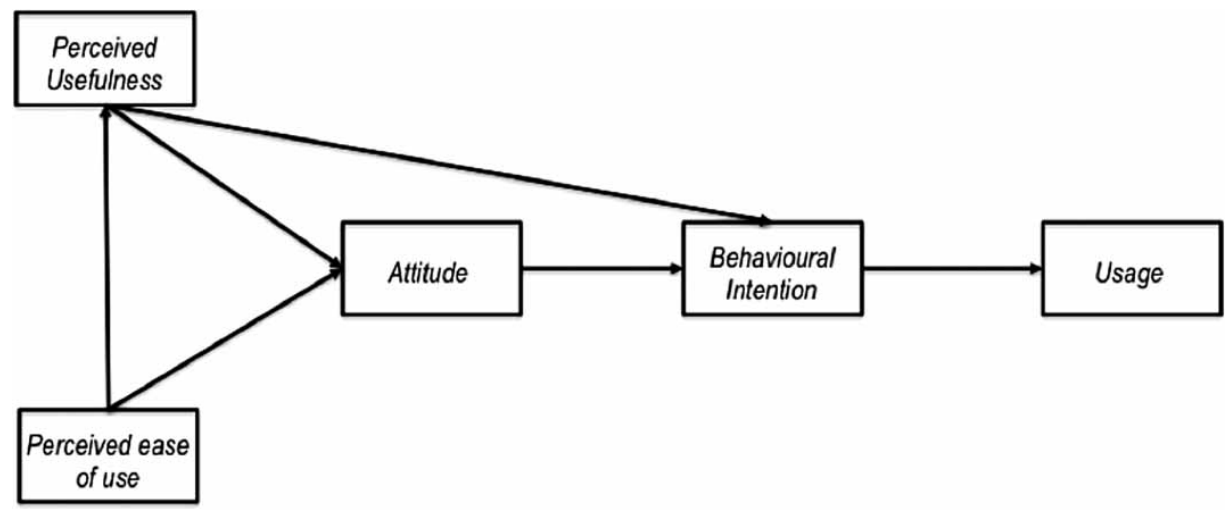

Figure 1: The Technology Acceptance Model

Source: Davis (1989). 


\section{Research problem}

With the widespread use of cell phones in South Africa and growing Internet penetration, the opportunity to expand financial inclusion through the use of technology is significant. The expansion of financial inclusion has been shown to contribute to poverty alleviation (Demirguc-Kunt, 2007; Beck et al., 2004, 2007). By studying the determinants of adoption of technology-enabled financial services, it may be possible to improve adoption rates and thus expand financial inclusion. No study has been identified that has investigated the ability of the TAM, or its extensions, to explain adoption of technology-enabled financial services in South Africa. The use of the TAM to study adoption of technology-enabled financial services was evaluated by searching various databases. Three large databases (ABI/Inform, Business Source complete and Social Sciences Citation Index) were searched. A total of 19 studies were identified in which the TAM, or modifications to the TAM, was used to study adoption of technologyenabled financial service. Rather than using a specific model such as TAM2 or User Acceptance of Information Technology, these studies used the original TAM as a basis and added additional constructs to better explain adoption in different settings. For this study it was decided to follow a methodological process to identify additional constructs that other studies had identified and determine whether it was possible to classify these additions in a meaningful way. In order to classify the additions, a grounded theory approach was used (Glaser \& Strauss, 1967; Corbin \& Strauss, 1990; Strauss \& Corbin, 1990). Grounded theory offers a way to compare and categorise similar qualitative concepts across different studies in a methodological way, through the use of a coding scheme (Strauss \& Corbin, 1990). The grounded theory approach has previously been used in studying information systems (Baskerville \& Pries-Heje, 1999; White \& Weatherall, 2000; Winkelman et al., 2005; Arcs \& Razali, 2009). While the use of the grounded theory method in the discipline of information systems is rare, it is a useful method for generating concepts about technology (Bryant \& Charmaz, 2007).

Using the grounded theory approach, five groups of constructs were produced, to each of which a descriptor was assigned. The first grouping of constructs, labelled self-efficacy, is based on the belief that one has the capabilities to execute the courses of actions required to manage prospective situations and the various emotions associated with executing such a decision. It includes factors such as belief, anxiety and perceptions about a person's control over the situation. This has been identified as an additional construct in mobile commerce (Bhatti, 2007; Lu \& Su 2009), online banking (Yaghoubi, 2010; Jaruwachirathanakul \& Fink, 2005; Yeow et al. 2008) mobile payments (Shin, 2009) and mobile banking (Luarn \& Lin, 2005). The second grouping was task and task-related variables, and was labelled task. This category of constructs relates to aspects of executing the task associated with the intended behaviour. It relates to information, effort, expected performance and resource expectancy in executing the tasks associated with the intended behaviour. This construct has been identified in a number of studies involving online banking (Pikkarainen et al., 2004; Yeow et al., 2008), mobile payment services (Yang et al., 2012), mobile commerce (Klopping \& McKinney, 2004) and mobile banking (Zhou et al., 2010).

A third category of construct, labelled trust, was associated with a person's uncertainty of whether undertaking a behaviour may result in risk, theft, loss of information or loss of privacy. This required people to develop the belief that undertaking the behaviour would be safe and would not expose them to such risks. Trust in banking is a significant 
component of why people entrust their money with an institution. This category has been identified as additional constructs in mobile commerce (Pavlou, 2003; Wu \& Wang, 2005), Internet banking (Wang et al., 2003; Amin, 2007; Riquelme \& Rios, 2010; Tan et al., 2010; Yousafzai et al., 2010) and mobile banking (Luarn \& Lin, 2005; Amin, 2009; Zhou, 2011). Trust-related constructs were found to have been one of the most significant additions to the field of technology-enabled service adoption. It was possible to group constructs that related to fun, enjoyment and pleasure into a single construct. The role of fun or enjoyment in adoption has been described to be of selffulfilling rather than instrumental value to the user (van der Heijden, 2004). The aspect of fun was less investigated, but was identified by researchers in mobile commerce (Lu \& Su, 2009) and in online banking (Pikkarainen et al., 2004). This grouping has been labelled hedonistic.

The final grouping of constructs, labelled social, related to how an individual perceives himself or herself within their broader social context, and in particular how they perceive that others would view their decisions. A number of studies have identified this as a construct in online banking acceptance (Amin, 2009), mobile banking (Riquelme \& Rios, 2010), mobile commerce (Bhatti, 2007), online banking (Tan et al., 2010; Yaghoubi, 2010) and mobile payment services (Shin, 2009; Yang et al., 2012). Social constructs have become an important addition to the TAM to better enable the understanding of adoption.

\section{Proposed expanded model of the TAM for adoption of technology-enabled services}

Using grounded theory it was possible to classify the additional constructs that various studies into technology-enabled financial service adoption identified into five broad categories. In addition to identifying additional constructs, the relationships between the additional constructs and the original constructs in TAM proposed by the authors were also analysed. These additional constructs as well as the relationships between them and the original TAM model provide a basis for an enhanced model of the TAM to better explain adoption (Wentzel, 2012). The proposed extension to the TAM is shown in Figure 2.

The introduction of these additional constructs to the original PU, PEOU and attitude constructs of the TAM allows one to propose an extension of the TAM that predicts the adoption of technology-enabled financial services. It is proposed that such additional constructs have an influence on Behavioural Intention (BI), which as per the original model will influence actual usage. The five additional constructs are shown as rectangles. The original factors of the TAM model are highlighted in grey.

\subsection{Testing the proposed extension of the TAM}

To validate the proposed model, the planned launch of a new bank in South Africa was studied. The new bank intends to offer its services through more than 2400 outlets of the national postal operator and to augment the traditional brick and mortar offering with technology-enabled channels such as cell phone banking, automated teller machines and Internet banking. It intends to use technology-enabled channels to increase the reach of the new bank while simultaneously reducing the cost of banking to its proposed customers. The primary focus of the new bank will be serving the poorer 


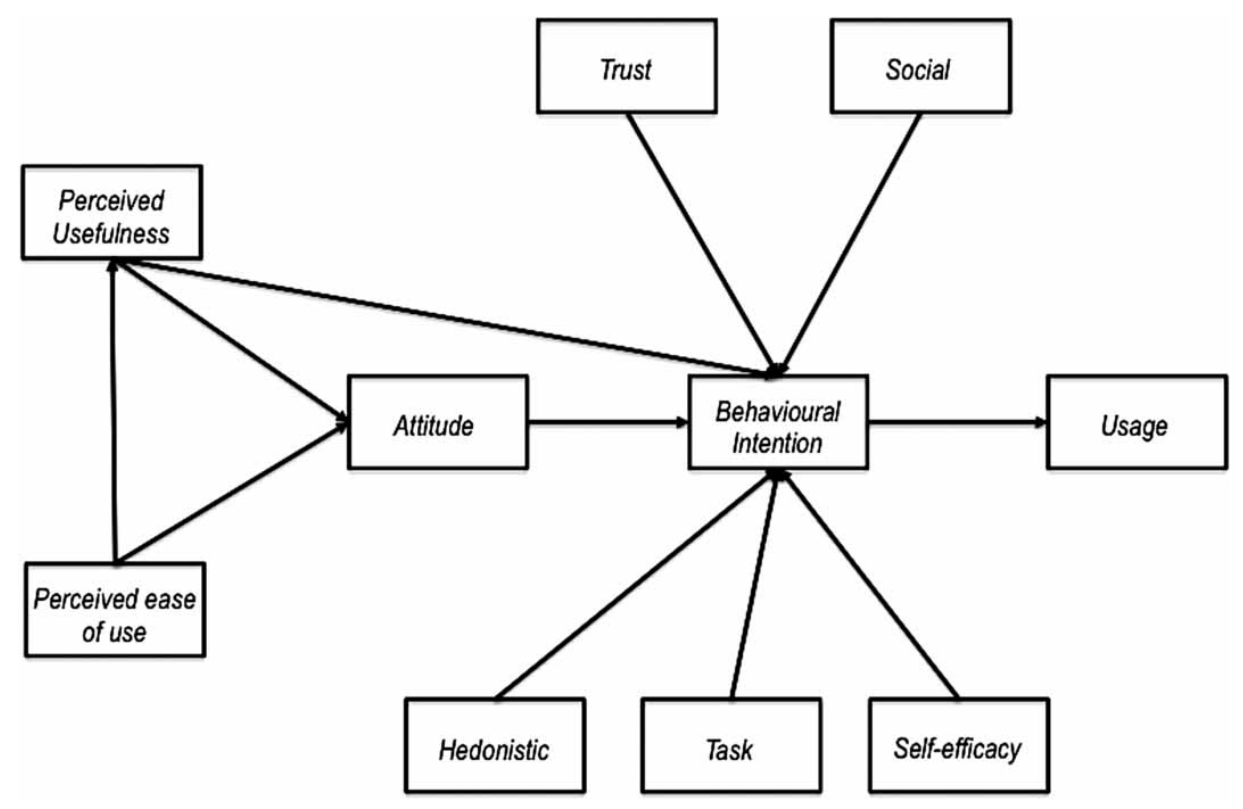

Figure 2: Proposed enhanced TAM for technology-enabled service adoption

portions of the population with a specific focus on the unbanked. Data were drawn as a subset from that collected as part of ongoing research into the bottom of the pyramid. Data were collected using face-to-face administered questionnaires. This approach offered advantages over self-completed questionnaires. From a respondent point of view this approach is probably the least burdensome method since it only requires the respondent to speak the same language in which the questions are asked, and to have basic verbal and listening skills. Face-to-face interview scores high on complete population coverage for sampling, low on cognitive burden for respondents, low for response choice order effects and highest for respondents' preferences for modes of administration compared with the alternatives; that is, telephone, electronic and selfcompleted (Bowling, 2005). The pre-testing of the designed questionnaire was done systematically using face validity, content validity and a pilot study (Cavana et al., 2001). The objective of the questionnaire framework was to obtain responses from the respondents in their natural habitat. The questionnaire sought to understand the role of money and the financial tasks respondents undertook on a daily, weekly and monthly basis. From a community perspective the questionnaire sought to identify access to infrastructure and access to facilities. From a technology perspective the questionnaire sought views on technology exposure and use.

As the research sought to study bottom-of-the-pyramid people there was a need to segment the population in a meaningful way to identify bottom-of-the-pyramid respondents. We decided to use the Living Standards Measure (LSM) to segment the population and identify the sample population that met the criteria for bottom of the pyramid. The South African Advertising Research Foundation developed the LSM in the 1980s for market segmentation. The LSM methodology categorises the entire population into 10 categories from LSM 1 to LSM 10. It is a household-level multiattribute segmentation tool based on access to services and durables and geographic 
indicators as determinants of the standard of living of a household. The LSM tool has been widely used for market segmentation and understating living conditions in South Africa (Møller, 1997; De Jager, 2004; Martins, 2004). An LSM survey is administered and data drawn at a household level, rather than at an individual level. The LSM was designed to divide the population of South Africa into manageable and meaningful sub-groups. The system has been used since 1993 and is based on the assumption that people behave similarly within a segment, and different to other segments. The methodology was designed to avoid the use of self-reported income as a basis for segmenting the population. Recently published All Media and Products Survey 2011 data on average household income as a function of LSM was used to determine the LSM cut-off value for the bottom of the pyramid (SAARF, 2011). The original definition of per-capita income was based on purchasing power parity, and the average dollar/rand exchange rate for 2011 was used to calculate the dollar equivalent of the per-capita income. From the analysis it was found that LSM 1to 4 cover the bottom of the pyramid in South Africa.

The sampling methodology sought to obtain a representative sample from the bottom of the pyramid and to adequately address the various issues of sampling bias that can arise. To ensure that the sample geographically represented the overall population, the classification of the entire country by enumerator areas (EAs) was used as the basis (Statistics South Africa, 2003). A total of 650 EAs were analysed for total population and average LSM. Using these data the appropriate EAs were selected and the number of required responses per EA were determined. Using the resultant data the sample was drawn proportional to population size in that EA. Between four and six interviewers were assigned per EA. To correctly identify respondents, two further levels of random sampling were deployed. Within each EA, households were randomly selected and individual respondents were then randomly selected from adults in each sampled household using the Kish grid method (Kish, 1949). This approach has also been followed by other studies into financial inclusion in South Africa (Finscope, 2010, 2011). The data collection produced a total of 1997 completed questionnaires covering LSM 1 to 6. From the LSM classification it was determined that 695 respondents in the sample could be classified as bottom of the pyramid. Based on the All Media and Products Survey 2011 data, the total LSM 1 to 4 population of adults 15 years and older in South Africa was 10542 000. The data consequently had a $3.72 \%$ confidence interval at a $95 \%$ confidence level. The research interest was in those people at the bottom of the pyramid who were unbanked; that is, did not hold a bank account of any description with a financial institution registered under the Banks Act of South Africa. Out of the sample of 695, a total of 341 did not hold bank accounts.

\section{Results}

A total of 341 respondents comprised the dataset. Prior to discussion of the results pertaining to the main explanatory model, notable descriptive statistics are reported. Table 1 shows the frequency measures for the key variables in the study.

Of the sample, $59.8 \%$ were female while $40.2 \%$ were male. This ratio is higher than the ratio for the country, which is $51.5 \%$ female and $48.5 \%$ male (Statistics South Africa, 2011). The difference could be due to the time of day when agents visited homes to conduct the survey, with males away working, but may also indicate that in rural 
Table 1: Frequency measures for the key variables

\begin{tabular}{|c|c|c|c|c|c|}
\hline Variable & Value & Frequency & $\%$ & Valid \% & Cumulative \% \\
\hline \multirow[t]{8}{*}{ Age } & $<25$ years & 57 & 16.7 & 16.7 & 16.7 \\
\hline & $25-34$ years & 104 & 30.5 & 30.5 & 47.2 \\
\hline & $35-44$ years & 59 & 17.3 & 17.3 & 64.5 \\
\hline & $45-54$ years & 40 & 11.7 & 11.7 & 76.2 \\
\hline & $55-64$ years & 36 & 10.6 & 10.6 & 86.8 \\
\hline & $65-74$ years & 30 & 8.8 & 8.8 & 95.6 \\
\hline & $>75$ years & 15 & 4.4 & 4.4 & 100 \\
\hline & Total & 341 & 100.0 & 100.0 & \\
\hline \multirow[t]{3}{*}{ Gender } & Female & 204 & 59.8 & 59.8 & 59.8 \\
\hline & Male & 137 & 40.2 & 40.2 & 100.0 \\
\hline & Total & 341 & 100.0 & 100.0 & \\
\hline \multirow[t]{3}{*}{ Area } & Metro & 55 & 16.1 & 16.1 & 16.1 \\
\hline & Non-metro & 286 & 83.9 & 83.9 & 100.0 \\
\hline & Total & 693 & 100.0 & 100.0 & \\
\hline \multirow[t]{9}{*}{ Primary source of Income } & Formal employment & 30 & 8.8 & 10.8 & 10.8 \\
\hline & Money from others & 67 & 19.6 & 24.2 & 35.0 \\
\hline & Government grants & 117 & 34.3 & 42.2 & 77.3 \\
\hline & Informal employment & 50 & 14.7 & 18.1 & 95.3 \\
\hline & Self-employment & 10 & 2.9 & 3.6 & 98.9 \\
\hline & Other & 3 & 0.9 & 1.1 & 100 \\
\hline & Total & 277 & 81.2 & 100.0 & \\
\hline & Declined to answer & 64 & 18.8 & & \\
\hline & Total & 341 & 100.0 & & \\
\hline \multirow[t]{6}{*}{ Education } & No schooling & 91 & 26.7 & 26.7 & 26.7 \\
\hline & Primary schooling & 205 & 60.1 & 60.1 & 86.8 \\
\hline & Some high schooling & 31 & 9.1 & 9.1 & 95.9 \\
\hline & Completed high schooling & 10 & 2.9 & 2.9 & 98.8 \\
\hline & $\begin{array}{c}\text { Post-high school } \\
\text { qualification }\end{array}$ & 4 & 1.2 & 1.2 & 100.0 \\
\hline & Total & 341 & 100.0 & 100.0 & \\
\hline
\end{tabular}

areas males migrate to the cities and remit money back to families. The largest age group in the sample was 25 to 34 years old (30.5\%), with the age group 35 to 44 making up the second largest group with $17.3 \%$. These figures are broadly in line with the country figures; however, the study measured from age 16 and older while the population estimates measure age brackets from 15 and older. Of the considered sample, 83.9\% lived outside major urban areas. The data show that people who live in rural areas are poorer than those living in urban areas, and show that the overwhelming majority of people at the bottom of the pyramid in South Africa live outside urban areas. Education levels of unbanked people at the bottom of the pyramid show a significant failure to complete formal education with only $2.9 \%$ of respondents having completed their high school education while $26.7 \%$ of respondents had no schooling at all. The problem of unemployment in South Africa is also clearly seen in the data, with a disproportionate portion of the unemployed living at the bottom of the pyramid. Only $8.8 \%$ of respondents were formally employed, whereas $91.2 \%$ are unemployed 


\section{Table 2: Variables loading onto constructs}

\begin{tabular}{|c|c|c|}
\hline Variable & Question & Construct \\
\hline Q142 & Overall Postbank concept rating & ATT \\
\hline Q143 & Postbank concept rating with respect to banking services - initial & ATT \\
\hline Q144 & Postbank concept rating with respect to government services & ATT \\
\hline Q145 & Postbank concept rating with respect to other services & ATT \\
\hline Q152C & Banking at the Post Office will be enjoyable & HED \\
\hline Q152E & You feel comfortable enough in a Post Office to try using an ATM & HED \\
\hline Q152H & Banking at the Post Office will be comfortable & HED \\
\hline Q152I & $\begin{array}{l}\text { The ATM and face-to-face over-the-counter services offered by the Post Office } \\
\text { will be as good as the other banks }\end{array}$ & HED \\
\hline Q147B & Post Office banking products will be easy to understand & PEOU \\
\hline Q147D & The Post Office will make banking easier & PEOU \\
\hline Q147G & Banking at the Post Office will help you do things you already do, but better & PEOU \\
\hline Q147L & Banking through the Post Office will be quicker than at normal banks & PEOU \\
\hline Q147M & Banking through the Post Office will be easy to use & PEOU \\
\hline Q147C & $\begin{array}{l}\text { You would use the Post Office to do banking because it will offer the services } \\
\text { that you need }\end{array}$ & PU \\
\hline Q147E & It will be good for you to bank through the Post Office & PU \\
\hline Q147H & You would be keen to try banking products offered at the Post Office & PU \\
\hline Q147J & $\begin{array}{l}\text { Banking at the Post Office will allow you to do banking services that you } \\
\text { cannot do yet }\end{array}$ & PU \\
\hline Q152A & You will bank at the Post Office if your family, friends or neighbours do & SOC \\
\hline Q152G & You would bank at the Post Office if your chief or community elders do & SOC \\
\hline Q152J & $\begin{array}{l}\text { You would bank at the Post Office if someone you respect like your } \\
\text { favourite radio show presenter or DJ does }\end{array}$ & SOC \\
\hline Q135E & You use their products or services - Post Office & TASK \\
\hline Q135M & They speak your own language - Post Office & TASK \\
\hline Q135AC & They treat you well - Post Office & TASK \\
\hline Q135AS & You can depend on them to get things done - Post Office & TASK \\
\hline Q135BA & They are cheap to use - Post Office & TASK \\
\hline Q135AK & People you trust use them - Post Office & TRUST \\
\hline Q135BI & You trust them with your money - Post Office & TRUST \\
\hline AV1 & Access to technology & TSE \\
\hline AV3 & Confidence using technology-enabled service & TSE \\
\hline AV5 & Actual use of technology & TSE \\
\hline
\end{tabular}

Note: ATM, automated teller machine.

compared with the national unemployment rate of $25.3 \%$. The significant disparity between urban and rural employment rates is evident, as $79 \%$ of respondents are from rural areas whereas $21 \%$ of respondents are from urban areas. South Africa has in recent years significantly expanded its social welfare programme. This programme provides basic grants (such as child support, disability and war veteran grants) as well as pensions to citizens who previously did not receive such support. At the bottom of the pyramid, unbanked respondent government grants (42.2\%) are the major source of income.

To construct a model to fit the data, confirmatory factor analysis was conducted. The analysis was conducted using IBM SPSS Statistics 20.0.0. For each construct in the 


\begin{tabular}{|c|c|c|c|c|c|}
\hline & & & Estimate & Standard error & Critical ratio \\
\hline Q147B & $\leftarrow$ & PEOU & 1.000 & & \\
\hline Q147G & $\leftarrow$ & PEOU & 1.501 & 0.166 & 9.068 \\
\hline Q147D & $\leftarrow$ & PEOU & 1.236 & 0.127 & 9.764 \\
\hline Q147L & $\leftarrow$ & PEOU & 1.417 & 0.152 & 9.343 \\
\hline Q147M & $\leftarrow$ & PEOU & 1.319 & 0.133 & 9.931 \\
\hline Q147J & $\leftarrow$ & PU & 1.000 & & \\
\hline Q147C & $\leftarrow$ & PU & 0.941 & 0.092 & 10.192 \\
\hline Q147H & $\leftarrow$ & PU & 0.971 & 0.097 & 10.023 \\
\hline Q147E & $\leftarrow$ & $\mathrm{PU}$ & 0.996 & 0.091 & 10.912 \\
\hline Q153 & $\leftarrow$ & ATT & 1.000 & & \\
\hline Q145 & $\leftarrow$ & ATT & 1.658 & 0.131 & 12.673 \\
\hline Q144 & $\leftarrow$ & ATT & 1.632 & 0.129 & 12.677 \\
\hline Q143 & $\leftarrow$ & ATT & 1.628 & 0.130 & 12.500 \\
\hline Q142 & $\leftarrow$ & ATT & 1.631 & 0.130 & 12.519 \\
\hline Q135AS & $\leftarrow$ & TASK & 1.000 & & \\
\hline Q135AC & $\leftarrow$ & TASK & 0.965 & 0.064 & 15.001 \\
\hline Q135M & $\leftarrow$ & TASK & 1.098 & 0.071 & 15.363 \\
\hline Q135E & $\leftarrow$ & TASK & 1.001 & 0.069 & 14.445 \\
\hline Q135BA & $\leftarrow$ & TASK & 0.861 & 0.066 & 13.081 \\
\hline AV5 & $\leftarrow$ & TSE & 0.394 & 0.110 & 3.581 \\
\hline AV3 & $\leftarrow$ & TSE & 0.474 & 0.133 & 3.572 \\
\hline AV1 & $\leftarrow$ & TSE & 1.000 & & \\
\hline Q152E & $\leftarrow$ & HED & 1.000 & & \\
\hline Q152I & $\leftarrow$ & HED & 1.102 & 0.115 & 9.610 \\
\hline Q152H & $\leftarrow$ & HED & 1.095 & 0.113 & 9.716 \\
\hline Q152C & $\leftarrow$ & HED & 1.120 & 0.115 & 9.781 \\
\hline Q152J & $\leftarrow$ & SOC & 1.000 & & \\
\hline Q152G & $\leftarrow$ & SOC & 0.947 & 0.073 & 12.930 \\
\hline Q152A & $\leftarrow$ & SOC & 0.715 & 0.060 & 12.005 \\
\hline Q135BI & $\leftarrow$ & TRUST & 1.000 & & \\
\hline Q135AK & $\leftarrow$ & TRUST & 1.278 & 0.091 & 13.981 \\
\hline
\end{tabular}

proposed model a number of variables were identified to test the construct. For each variable (with the exception of three), respondents were asked to answer a question using a five-point Likert scale. Three of the variables (AV1, AV2 and AV5) were derived by summating 10 questions that had dichotomous responses. The list associated with each of the proposed constructs is shown in Table 2.

The critical ratio (the parameter estimate divided by the estimate of the standard error) was inspected to determine whether the loadings of the variables on the constructs were acceptable. If the estimate has a critical ratio greater than 1.96 , the estimate is significant at the 0.05 level. If the critical ratio is greater than 2.58 , then the estimate is significant at the 0.01 level. All of the variable loadings onto the latent factors were greater than 2.58, indicating significance loading at the 0.01 level. The variables are thus good indicators of the underlying constructs in the proposed model. The unstandardised factor loadings are shown in Table 3. 


\section{Table 4: Model fit measures}

\begin{tabular}{lccccc}
\hline Model & NFI, $\boldsymbol{\Delta 1}$ & RFI, $\boldsymbol{\rho 1}$ & IFI, $\boldsymbol{\Delta 2}$ & TLI, $\mathbf{\rho 2}$ & CFI \\
\hline Baseline comparisons & & & & & \\
$\quad$ Default model & 0.891 & 0.876 & 0.968 & 0.963 & 0.968 \\
Saturated model & 1.000 & & 1.000 & & 1.000 \\
Independence model & 0.000 & 0.000 & 0.000 & 0.000 & 0.000 \\
RMSEA & RMSEA & LO 90 & HI 90 & PCLOSE & \\
Default model & 0.033 & 0.026 & 0.039 & 1.000 & \\
Independence model & 0.172 & 0.168 & 0.176 & 0.000 & \\
\hline
\end{tabular}

Notes: CFI, Comparative Fit Index; HI 90, upper bound of the 90\% confidence interval; IFI, Incremental Fit Index; LO 90, lower bound of the 90\% confidence interval; NFI, Normed Fit Index; PCLOSE, probability of a hypothesis test that the population RMSEA is no greater than 0.05; RFI, Relative Fix Index; RMSEA, Root Mean Square Error of Approximation; TLI, Tucker-Lewis Index.

The acceptability of the fitted confirmatory factor analysis solution should be evaluated on the basis of three major aspects: overall goodness of fit; the presence or absence of localised areas of strain in the solution; and the interpretability, size, and statistical significance of the model's parameter estimates (Brown, 2006). Researchers are advised to consider and report at least a single index from each category when evaluating the fit of their models (Jackson et al., 2009). It has been reported that after $\chi^{2}$ values the most commonly reported measures of fit were the Comparative Fit Index, the root mean square error of approximation (RMSEA) and the Tucker-Lewis Index (Jackson et al., 2009). The use of $\chi^{2}$ values is based on the normality of the data. An assessment of normality of the data found that seven of the 27 variables displayed non-normality, as shown by a critical ratio of the kurtosis that was outside the acceptable range of +2.00 to -2.00 . To deal with the non-normality a bootstrap approach was used and the Bollen-Stine $\mathrm{p}$ value as a measure of fit was reported. A total of 2000 bootstrap samples were used. The fit of the data to the confirmatory factor analysis was good. A Bollen-Stine $\mathrm{p}$ value of 0.151 was obtained. This value was above 0.05 , the cut-off point where the null hypothesis that the model data do not fit the data must be rejected. The Comparative Fit Index for the model was 0.968, which is greater than 0.90 (acceptable fit) and 0.95 (good fit). The RMSEA is 0.033 . The guidelines for the RMSEA are that values below 0.05 indicate good fit while values between 0.05 and 0.06 indicate acceptable fit. The RMSEA fit was thus good. The range at the $95 \%$ confidence level for the RMSEA was also within the values for a good fit $(0.026,0.039)$. The Tucker-Lewis Index for the model was 0.963 , which is greater than the guideline for good fit. The model fit indices are shown in Table 4. Based on the analysis, one concludes that the proposed model is a good fit to the data, and cannot be rejected.

To determine the factor scores for each latent factor we used the non-refined method of determining the average of the unstandardised factor loadings scores for all variables loading onto a factor (Comrey \& Lee, 1992). From this analysis, attitude $(\bar{x}=1.510)$ was found to be most significant construct. The second most significant construct was PEOU $(\bar{x}=1.295)$, followed by trust $(\bar{x}=1.139)$. The least significant factor was found to be technology self-efficacy $(\bar{x}=0.623)$ preceded by social $(\bar{x}=0.887)$. 


\section{Conclusions}

The results of the research study show that the proposed enhancement of the TAM through the addition of five additional constructs is a good fit to the data when considering the adoption of a technology-enabled service such as banking in South Africa. The proposed model incorporates social factors, self-efficacy, fun, trust and task as additional constructs in the TAM. The incorporation of these constructs in addition to PEOU, PU and attitude allows a better understanding of the adoption intention of potential customers for technology-enabled banking services. The study has built on previous work such as Amin (2009) and Riquelme \& Rios (2010) in which an extended TAM was used to successfully study mobile banking adoption. The studies highlighted the methodological approach of identifying additional constructs that when added to the original TAM allow successful modelling of financial services adoption. Using the non-refined method it was also determined that attitude was the most significant factor in the model, followed by PEOU, while social factors and technology self-efficacy were the least significant. The findings highlight implications for the launch of the new bank that its management should not ignore.

Attitude was found to be the most important construct in the model. Bottom-of-the-pyramid unbanked peoples' attitude may be informed by perceived benefits that using technologyenabled financial services may bring. It may be important for the new bank to explain the benefits of using financial services so that people's opinions may be positively influenced. The results show that it would be important to provide products and services that are easy to use. People at the bottom of the pyramid may lack education and consequently products and services will need to take this into account. Peoples' trust in technology-enabled financial services was also found to be the third most important construct. It will be important that the new bank should instil trust in unbanked bottom-of-the-pyramid customers. In addition to the original constructs of perceived usefulness, the importance of social factors, fun and how the proposed technology-enabled financial services meets the needs of bottom-ofthe-pyramid customers are also important. These findings provide an insight into what messages the marketing of these services will need to contain if potential customers are to adopt the service.

\section{References}

Adams, D, Nelson, R \& Todd, P, 1992. Perceived usefulness, ease of use, and usage of information technology: A replication. MIS Quarterly 16(2), 227-47.

Ajzen, I, 1991. The theory of planned behavior. Organizational Behavior and Human Decision Processes 50, 179-211.

Amin, H, 2007. Internet banking adoption among young intellectuals. Journal of Internet Banking and Commerce 12. http://www.arraydev.com/commerce/jibc/ Accessed 12 January 2012.

Amin, H, 2009. An analysis of online banking usage intentions: An extension of the Technology Acceptance Model. International Journal Business and Society 10(1), 27-40.

Arcs, G \& Razali, R, 2009. Cognitive dimensions and grounded theory in learning software modeling. Procedia - Social and Behavioral Sciences 1(1), 1884-8.

Bagozzi, R, 2007. The legacy of the Technology Acceptance Model and a proposal for a paradigm shift. Journal of the Association for Information Systems 8(4), 244-54.

Baskerville, R \& Pries-Heje, J, 1999. Grounded action research: A method for understanding IT in practice. Accounting, Management and Information Technologies 9(1), 1-23.

Beck, T, Demirguc-Kunt, A \& Levine, R, 2004. Finance, inequality and poverty: Cross-country evidence. World Bank Policy Research Working Paper No. 3338, World Bank, Washington, DC. 
Beck, T, Demirguc-Kunt, A \& Martines-Peria, M, 2007. Reaching out: Access to and use of banking services across countries. Journal of Financial Economics 85, 234-66.

Bhatti, T, 2007. Exploring factors influencing the adoption of mobile commerce. In Journal of Internet Banking and Commerce 12. http://www.arraydev.com/commerce/jibc/ Accessed 12 January 2012.

Bowling, A, 2005. Mode of questionnaire administration can have serious effects on data quality. Journal of Public Health 27(3), 281-91.

Brown, TA, 2006. Confirmatory Factor Analysis for Applied Research. Guilford, New York.

Bruner II, G \& Kumar, A, 2005. Explaining consumer acceptance of handheld Internet devices. Journal of Business Research 58, 553-8.

Bryant, A \& Charmaz, K, 2007. The SAGE Handbook of Grounded Theory. SAGE, London, New Delhi, California and Singapore.

Cavana, R, Delahye, BL \& Sekaran, U, 2001. Applied Business Research: Qualitative and Quantitative methods. Wiley, Milton, Australia.

Chuttur, M, 2009. Overview of the Technology Acceptance Model: Origins, developments and future directions. In Sprouts: Working Papers on Information Systems. http://sprouts.aisnet. org/9-37 Accessed 5 January 2012.

Comrey, A \& Lee, H, 1992. A First Course in Factor Analysis. 2nd edn. Erlbaum, NJ.

Corbin, J \& Strauss, A, 1990. Grounded theory research: Procedures, canons, and evaluative criteria. Qualitative Sociology 13, 3-21.

Davis, F, 1986. A Technology Acceptance Model for Empirically Testing New End-User Information Systems: Theory and Results. Massachusetts Institute of Technology, Cambridge, MA.

Davis, F, 1989. Perceived usefulness, perceived ease of use, and user acceptance of information technology. MIS Quarterly 13(3), 319-40.

Davis, F, Bagozzi, R \& Warshaw, P, 1989. User acceptance of computer technology: A comparison of two theoretical models. Management Science 35(8), 982-1003.

De Jager, N, 2004. The Living Standards Measure as a Market Segmentation Tool for Selected Retailers. North-West University, Potchefstroom Campus, South Africa.

Demirguc-Kunt, A, 2007. Finance and Economic Development: Policy Choices for Developing Countries. Policy Research Working Paper Series 3955, The World Bank, Washington, DC.

Finscope, 2010. Finscope South Africa 2010. Finmark Trust, Johannesburg.

Finscope, 2011. Finscope South Africa 2011. Finmark Trust, Johannesburg.

Fishbein, M \& Ajzen, I, 1975. Belief, Attitude, Intention, and Behavior: An Introduction to Theory and Research. Addison-Wesley, Reading, MA.

Glaser, B \& Strauss, A, 1967. The Discovery of Grounded Theory. Aldine, Chicago.

Igbaria, M, Zinatelli, N, Cragg, P \& Cavaye, A, 1997. Personal computing acceptance factors in small firms: A structural equation model. MIS Quarterly 21(3), 279-302.

Jackson, D, Gillaspy, J \& Purc-Stephenson, R, 2009. Reporting practices in confirmatory factor analysis: An overview and some recommendations. Psychological Methods 14(1), 6-23.

Jaruwachirathanakul, B \& Fink, D, 2005. Internet banking adoption strategies for a developing country: The case of Thailand. Internet Research 15(3), 295-311.

Kish, L, 1949. A procedure for objective respondent selection in a household. Journal of the American Statistical Association 44, 380-7.

Klopping, I \& McKinney, E, 2004. Extending the Technology Acceptance Model and the tasktechnology fit model to consumer e-commerce. Information Technology, Learning, and Performance Journal 22(1), 35-48.

Lu, H-P \& Su, P, 2009. Factors affecting purchase intention on mobile shopping web sites. Internet Research 19(4), 442-58.

Luarn, P \& Lin, H-H, 2005. Toward an understanding of the behavioral intention to use mobile banking. Computers in Human Behavior 21, 873-91.

Martins, J, 2004. Household income and expenditure in Gauteng by living standards measure (LSM) group, 2003. Issue 332 of Research Report, Bureau of Market Research, University of South Africa, Pretoria, South Africa. 
Møller, V, 1997. Quality of Life in South Africa. Vol 1 of Social Indicator Research Series. Kluwer Academic Publishers, Boston, Dordrecht and London.

Moon, J-W \& Kim, Y-G, 2001. Extending the TAM for a World-Wide-Web context. Information \& Management 38, 217-30.

Ngwane, A, Yadavalli, V \& Steffens, F, 2001a. Income inequality in South Africa - A statistical analysis. Studies in Economics and Econometrics 25(1), 63-75.

Ngwane, A, Yadavalli, V \& Steffens, F, 2001b. Poverty in South Africa - A statistical analysis. Development Southern Africa 18(2), 201-16.

Pavlou, P, 2003. Consumer acceptance of electronic commerce: Integrating trust and risk with the Technology Acceptance Model. International Journal of Electronic Commerce 7(3), 101-34.

Pikkarainen, T, Pikkarainen, K, Karjaluoto, H \& Pahnila, S, 2004. Consumer acceptance of online banking: An extension of the technology acceptance model. Internet Research 14(3), 224-35. Prahalad, C, 2006. The Fortune at the Bottom of the Pyramid. Pearson Prentice Hall, New Delhi. Prahalad, C \& Hart, S, 2002. The fortune at the bottom of the pyramid. Strategy+Business 26(1), $1-26$.

Prahalad, C \& Hammond, A, 2002. Serving the world's poor profitability. Harvard Business Review September, 48-57.

Riquelme, H \& Rios, R, 2010. The moderating effect of gender in the adoption of mobile banking. International Journal of Bank Marketing 28(5), 328-41.

Shin, D-H, 2009. Towards an understanding of the consumer acceptance of mobile wallet. Computers in Human Behavior 25, 1343-54.

SAARF (South Africa Advertising Research Foundation), 2011. LSM Description Slides - March 2011. http://www.saarf.co.za/LIFESTYLE/lifestyle.htm Accessed 12 January 2012.

Statistics South Africa, 2003. Census 2001: Concepts and Definitions. Statistics South Africa, Pretoria, South Africa.

Statistics South Africa, 2011. Mid-year Population Estimates, 2011. http://www.statssa.gov.za/ publications/statsdownload Accessed 12 January 2012.

Strauss, A \& Corbin, J, 1990. Basics of Qualitative Research: Grounded Theory Procedures and Techniques. Sage, London.

Tan, G, Chong, C-K, Ooi, K-B \& Chong, A, 2010. The adoption of online banking in Malaysia: An empirical analysis. International Journal of Business and Management Science 3(2), 169-93.

Taylor, S \& Todd, P, 1995. Assessing IT usage: The role of prior experience. MIS Quarterly 19(4), $561-70$.

Tejerina, L, Bouillon, C \& Demaestri, E (Eds), 2006. Financial Services and Poverty Reduction in Latin America and the Caribbean. Inter-American Development Bank, Washington, DC.

van de Wijngaert, L \& Bouman, H, 2009a. Coppers context, and conjoints: A reassessment of TAM. Journal of Information Technology 24, 186-201.

van de Wijngaert, L \& Bouman, H, 2009b. Would you share? Predicting the potential use of a new technology. Telematics and Informatics 26(1), 85-102.

van der Heijden, H, 2003. Factors influencing the usage of websites: The case of a generic portal in The Netherlands. Information \& Management 40, 541-9.

van der Heijden, H, 2004. User acceptance of hedonic information systems. MIS Quarterly 28(4), $695-704$.

Venkatesh, V, 2000. Determinants of percieved ease of use: Integrating control, intrinsic motivation and emotion into the technology acceptance model. Information Systems Research 11(4), 342-65.

Venkatesh, V \& Davis, F, 2000. A theoretical extension of the technology acceptance model: Four longitudinal field studies. Management Science 46(2), 186-204.

Venkatesh, V \& Morris, M, 2000. Why dont men ever stop to ask for directions? Gender, social influence and thier role in technology acceptance and usage behaviour. MIS Quarterly 24(1), 115-39.

Venkatesh, V, Morris, M, Davis, G \& Davis, F, 2003. User acceptance of information technology: Toward a unified view. MIS Quarterly 27(3), 425-78. 
Wang, Y-S., Wang, Y-M., Lin, H-H \& Tang, T-I, 2003. Determinants of user acceptance of Internet banking: an empirical study. International Journal of Service Industry Management 14(5), 501-19.

Wentzel, J, 2012. Modelling financial services adoption through an intermediary in South Africa: TAM and SEM approach. Unpublished PhD thesis, University of Pretoria.

White, J \& Weatherall, A, 2000. A grounded theory analysis of older adults and information technology. Educational Gerontology 26(4), 371-86.

Winkelman, W, Leonard, K \& Rossos, P, 2005. Patient-perceived usefulness of online electronic medical records: Employing grounded theory in the development of information and communication technologies for use by patients living with chronic illness. Journal of the American Medical Informatics Association 12(3), 306-14.

World Bank, 2009. World Bank GINI index. http://data.worldbank.org/indicator/SI.POV.GINI/ Accessed 19 March 2012.

Wu, J-H \& Wang, S-C, 2005. What drives mobile commerce? An empirical evaluation of the revised technology acceptance model. Information \& Management 42, 719-29.

Yaghoubi, N-M, 2010. Factors affecting the adoption of online banking An integration of Technology Acceptance Model and Theory of Planned Behavior. International Journal of Business and Management 9(5), 159-65.

Yang, S, Lu, Y, Gupta, S, Cao, Y \& Zhang, R, 2012. Mobile payment services adoption across time: An empirical study of the effects of behavioral beliefs, social influences, and personal traits. Computers in Human Behavior 28, 129-42.

Yeow, P, Yuen, Y \& Tong, D, 2008. User acceptance of online banking service in Australia. Communications of the IBIMA 1, 191-7.

Yousafzai, S, Foxall, G \& Pallister, J, 2010. Explaining internet banking behavior: Theory of Reasoned Action, Theory of Planned Behavior, or Technology Acceptance Model? Journal of Applied Social Psychology 40(5), 1172-202.

Zhou, T, 2011. An empirical examination of initial trust in mobile banking. Internet Research 21(5), 527-40.

Zhou, T, Lu, Y \& Wang, B, 2010. Integrating TFF and UTAUT to explain mobile banking user adoption. Computers in Human Behavior 26, 760-7. 